\title{
A Teacher's Beliefs and Practices of Using Video to Teach Speaking: A Case Study at SMA As-Salam Surakarta
}

\author{
Ummy Khoirunisya' Masyhudianti ${ }^{1}$ \\ ${ }^{1}$ Graduate School, English Education Department, SebelasMaret University \\ ukhoirunisya@gmail.com \\ Hanita Masithoh $^{2}$ \\ ${ }^{2}$ Graduate School, English Education Department, SebelasMaret University \\ ${ }^{2}$ hanitamasithoh@yahoo.com \\ Khoirunnisa $^{3}$ \\ ${ }^{3}$ Graduate School, English Education Department, SebelasMaret University \\ annisanisa662@gmail.com
}

\begin{abstract}
In the 21 st century era, the implementation of technology in the form of common digital media and resources has been applied by teachers in language teaching and learning process. One of the digital media broadly used in teaching is video. It provides many advantages to promoteand improve students' speaking skill. This study aims to investigate the teacher's beliefs and the practices of using video in teaching speaking at the Ten Grade of SMA As-Salam Surakarta. A qualitative method was employed as the design of this study. An English teacher voluntarily involved as the participant. The data were collected through in depth-interview. The findings were categorized into three majors: 1) Teacher's belief in teaching speaking using video; 2) The reflection of those beliefs in classroom practices; 3) Factors shaping the teacher's beliefs and the practices. The result showed that there is no discrepancy between the teacher's beliefs and teaching practices. This study has a contribution to the development of English foreign language teaching. Hence, it is suggested that the English teacher should highlight their beliefs in order to create effective teaching practices.
\end{abstract}

ARTICLE HISTORY

Received 8 April 2018

Accepted 27 August 2018

\section{KEYWORDS}

Video;speaking;teacher's beliefs;case study

\section{Introduction}

In this 21 st century era, technology has become a significant aspect and has lighted the new teaching paradigm in English language teaching. It also supports a social and human infrastructure for teachers and students to enhance collaboration, interaction, and participation in the classroom as well as facilitate them to create constructive learning environments (Chen, 2011). Moreover, the Partnership Forum for 21stCentury Skills (P21) confirms, "today no organization can achieve results without incorporating technology into every aspect of its everyday practices. It is time for schools to maximize the impact of technology as well" (P21, 2008c: 2). However, it 
becomes one of the challenges for the teachers to adapt to this globalization era because the teacher must adapt to the technology where traditional approaches to learning and teaching English are no longer appropriate.

The implementation of technology in the form of common digital media and resources has been applied by teachers in language teaching and learning process, for instance using Video, Audio, PowerPoint presentation, and others. in teaching speaking. Hence, it is interesting to know whether teachers' beliefs are affecting the use of technology (e.g., video) in the classroom or not. Teachers have a belief that teaching speaking using video will be more effective if it is in line with its implementation. In other words, Korthagen (2004) says that teachers are likely to be the most effective when their beliefs reflect their instructional practices in the classroom. Teachers' beliefs can also influence their behavior (Ajzen\& Madden, 1986; Xu 2012). Pajares (1992) highlighted that teachers' beliefs have a greater impact than the teachers' knowledge on planning their lessons, on what decisions they make, what general classroom practice they implement. They are used to understanding and improving educational processes (The Organization for Economic Co-operation and Development (OECD), 2009; Fauziati, 2015). Teachers' beliefs are related to teachers' strategies to deal with challenges in their daily professional life and to their general well-being, and they make students' learning environment and affect students' motivation and achievement (OECD, 2009; Fauziati, 2015).

Theoretically, Belief itself deals with the assumption, perspective, knowledge, and understanding accepted to be true that serves as a guide to think and to behave (Pajares, 1992; wood, 1996; and Borg, 2001), while teacher's belief is an assumption, perspective, and cognitions about teaching and learning (Kagan, 1992: 65 and Borg, 2003: 81). What teacher do or act will reflect their belief and it can be in the form of classroom practices such as the method, procedure, material, interaction, instruction, and so on (Richards \& Lockhart, 1994: 30; Wiliam\&Burden, 1997: 56; Breen, et al., 2001: 473; Richard \& Rodgers, 2001; Borg, 2003; and Fauziati, 2015: 53).

In term of language teaching, teacher's belief can be divided into some categories such as belief about English, belief about learning, belief about teaching, belief about program and curriculum, and belief about teaching as a profession (Richard \& Lockhart, 1994). In accordance with belief about teaching, teachers have a crucial role in teaching learning process since teaching is more than transferring knowledge. Teaching is an activity of helping students to learn, guiding students to understand, or even counseling students to overcome their difficulties. Richard and Lockhart (1994: 36-37) maintain that teaching is a very personal activity and every teacher has a different assumption about it.

Regarding the 21 st century, the use of technology is a must that the teacher can use it in teaching and facilitate the students to reach the goal, one of them is video. The video is an audiovisual material which helps students learning at their own pace 
that cause a meaningful learning process (Secer et al., 2015). It is also excellent of the authentic spoken material source that is attractive and motivating (Ur, 1996). Hence, it has significant advantages to the student learning English. Kennedy (1979) depicts video as a valuable aid that can increase teaching program as well as develop oral skills. Cahyono (1997:134) explains that the use of video can offer a unique and exciting learning experience for teachers and students if they are used constructively and in varied activities that support student-centered. Besides, Harmer (2001:282) says that the use of video will infuse a particular, extra dimension in a learning experience. The students can learn language-in-use in which they can hear the intonation, observe the gestures and mimics, and interpret the meaning of the speakers' expression. In other sides, the students' cross-cultural awareness will improve since they watch and observe how native speakers' speak, what accent they use, what topic they commonly talk, what clothes they wear, and others. Moreover, watching video is an enjoyable activity which can promote students' motivation. Then, giving the students an interesting task to create a video will foster the students' creativity in exploring language use.

In line with Harmer, Stemplesky (2002:364) points out that the use of video in teaching can support the possibility of motivating students' interest, stimulating language use, giving realistic listening practice and enhancing students' awareness of particular language points or other aspects of communication. Again, Erben et al. (2009:82) explain that seeing the person communicating in the video assists learners to comprehend the content of the video because the will also see person's body language and facial expressions to understand the meaning of a message. To conclude, the video is not only authentic material that provides comprehensible input of English but also motivates the students in learning. Moreover, it assists the students in mastering speaking skill that covers linguistics and the culture of English use.

There are several types of research has been conducted in the area of benefiting video technology in ELT. Irawati (2016) conducted research in supporting student's English speaking achievement using video. The result reveals that the use of video as teaching media can be one of the solutions to improve not only the students' speaking skills but also their' positive attitude in the teaching of speaking. Furthermore, some other researches show that there is a significant difference of students' speaking skill after being taught using video (Hakim, 2016; Octavia, 2015; AS, 2014; Saleng et al., 2014; Mustikawati, 2013). These findings reveal that video is effective in teaching speaking

Moreover, some other researches focusing on the teacher's beliefs on technology integration also have been conducted by prior researchers. Prestidge (2012) researched the beliefs behind the teacher that influences their ICT practices. The results show specific links between ICT beliefs and ICT practices that are aligned to reform agenda for digital pedagogies. The findings of this research show 
that the teachers' beliefs inform their ICT practices in the classroom.

Subsequently, Kim et al. (2013) researched teacher beliefs and technology integration. The results reveal that those teachers' beliefs about the nature of knowledge and learning, beliefs about effective ways of teaching and technology integration were significantly correlated with one another.

Based on the researches above, further research in a specific way which investigates the teacher's belief in the use of video in teaching and learning process is significant. According to the preliminary research done in one of the private senior high schools in Surakarta, Indonesia, it was found that the teacher benefits video in teaching speaking. Therefore, this study tried to address three major questions:

1. What are the teacher's beliefs on video to teach speaking?

2. How are those beliefs in teaching speaking reflected in classroom practices?

3. What are factors that affect the shaping of those beliefs?

\section{Method}

A qualitative case study is research which tends to explore depth phenomenon and provide the best understanding of a research problem by revealing the general characteristic of issues (Creswell, 2012: 17; Tuckman, 1999: 38; and Gall, Gall \& Borg, 2003: 434). In line with the explanation above, this study employs a qualitative case study to explore the teacher's belief, the classroom practices, and the affecting factors.

Furthermore, an English teacher was involved in this study. The teacher graduated from Muhammadiyah University of Surakarta and currently a master student of SebelasMaret University. She has experience in teaching English formal and informal education for more than three years. Currently, she teaches grade $\mathrm{X}$ in SMA As-Salam Surakarta.

The data collected through in-depth interview Interview is used to provide structured data with greater depth (Gall, Gall \& Borg: 2003). It is used to find out teacher's belief on video to teach speaking, the classroom practices, and factors shaping her beliefs.

In analyzing the data, the researchers adapt Braun and Clarke (2006) analytical procedures. The steps begin with transcribing the set of answers. After that, the transcripts are read and re-read many times to identify the required data. In the next step, the identified data are put into meaningful codes. Then, the codes are analyzed and combined to form categories. Next, the categorized data are reviewed to discover explicit mapping. The last, the clear mapping are analyzed in detail and reported into research finding. 


\section{Results and Discussions}

\section{Teacher's Belief about Teaching Speaking Using Video}

Regarding the topic of this study, it is very crucial knowledge about teacher's belief in using video in teaching speaking. According to Richards and Lockhart (1994: 3637), teachers' beliefs about teaching include their beliefs in the classroom as well as the clear implementation, the method or media implemented, teaching resources, effective teaching, classroom management, and qualities of a good language teacher. Hence, the teacher believed that it is essential using technology such as video in teaching speaking in the 21st-century era. Interestingly, her belief has reflected the activity in teaching practice. Moreover, the teachers' role in the classroom is as a facilitator, for instance, she facilitated what students need in the classroom and also as a counselor because she also helped the students when they got a problem - the teacher defined video as one of the teaching aids using in the teaching-learning process. It includes to multimodal text, for instance, audiovisual. Regarding the source of the video showed in the classroom, it was a conversation from an English native speaker, and animation got from You-tube that was based on the topic studied.

The teacher also says that teaching speaking is the easiest one because by using video students can practice and imitate it. As a result, students will be more interested, enjoyed, and motivated in learning. It is in line with Ur (1996) that says the video is excellent of authentic spoken material sources that is attractive and motivating. Hence, it has significant advantages for the students in learning English. Kennedy (1979) depicts video as a valuable aid that can increase teaching program as well as develop oral skills. It was proven that students learn how to pronounce the word correctly like an English native speaker so that it is useful to enhance students' speaking abilities. Automatically, by seeing the video, it does improve not only students' pronunciation but also their fluency, vocabulary, grammar, and comprehension.

Moreover, according to the teacher, effective teaching in speaking using video can be reached if the students can understand the material and their speaking skill can be improved so that they can practice it in daily life situation. Subsequently, in the classroom, there are active and passive students, and she believed that by asking the active students to collaborate with passive one will motivate the passive one in speaking. Regarding good qualities of an English teacher, she said that a teacher must be competent with the knowledge she has and teacher must be willing to explore other types of learning styles to pass on knowledge and be ready to try different methods when one does not work. A good language teacher must be passionate about teaching the language. Furthermore, a good language teacher should be able to assess the learning that her or his students have done and made improvement based on those assessments. 


\section{The Reflection of Those Beliefs in Classroom Practices}

This section explored the reflection of the English teacher's beliefs in teaching practices, classroom management, and students' attitudes. The results discussed here are obtained through an in-depth interview.

The teaching activities begin with overviewing the topic will be discussed. The teacher said, "I delivered what material will be discussed." Then, she stimulated students' curiosity by asking some questions related to the topic. Those activities are significant since it activates the background knowledge. As stated by Bouman (1990) in Irawati (2016: 53), previewing activities can be presented by activating schema and providing information related to the topic that will be presented in the video.

The next activity is showing the video. In this section, the students had to understand what the video talks about. It is in line with Harmer's explanation about activities that can be done by the student using video in class. The students watch the video intended to look for as much information as they can get from the video (2001: 287). This not only focuses on the general but also specific information of the video. The students learned the content as well as speaking components, such as vocabulary, fluency, and grammar.

Furthermore, the students were given a chance to ask everything they have not understood yet about the video they watched. The question could be about the topic of the materials, language use, or utterance in the video. In this section, the students were encouraged to be more active. Moreover, the teacher's role is not only as a facilitator but also as a counselor.

Then, at the end of the section, the students were given a situational conversation. They practice it in pairs or groups depending on the need. It is called as following up or consolidating step. Bouman (1990) in Irawati (2016: 53) stated that following up step aims to develop students' creativity in using the target language. It can be in the form of role-playing, discussion, or group debate. The teachers managed the class by dividing students into some groups. Each group consists of active and passive students in order to make the passive become motivated in speaking class.

Based on the explanations above, it could be concluded that the teacher used some steps in teaching speaking using video such as: previewing, viewing, exploiting, reviewing, and consolidating. Besides, the students showed that they were enthusiastic in learning to speak through video. Most of them were more motivated in learning speaking. The teacher stated, "They not only get a high result but also increase their speaking skill." Harmer supports this, 2001: 282; Stemplesky, 2002: 364 . They stated that use video would add special dimension in learning experience since it can motivate students' interest, provide realistic language use, and highlight students' awareness of particular language points. 


\section{Factors Shaping a Teacher's Beliefs and the Practices}

Factors that influence a teacher's beliefs may come from the teacher's own experience as language learners, the experience of what works best, established practices, personality factors, educationally based or research-based principles, principles derived from an approach or method (Richards \& Lockhart, 1994: 30-31). In this study, the researchers interviewed a teacher in order to investigate those factors. It is found that several factors shaped a teacher's belief. It can be explained as follows.

a. Learning Experience

The teacher's learning experience came from her experience as a language learner. She said that she was inspired by her lecturer who taught speaking skill through video. The lecturer showed the video about how to be a good debater and asked the students to practice. The video gave the real example to the students, so they can grasp the materials easier. It can enrich the method and technique in the debate. From the teacher's explanation, it can be concluded that learning experience gives impact on her beliefs and practices.

b. Teaching Experience

Experience is necessary to enhance the way in teaching students. It has a big impact on shaping the teacher's belief and practices. The teacher mentioned that the more she practiced teaching-learning, the more she would be easy to handle the students. Professional development activities can support it. These activities are aimed to change teachers' knowledge, beliefs and instructional practices. The teacher has experience in joining Macromedia workshop in order to enhance her ability in using technology.

\section{c. Personality Factors}

The teacher believed that using video in delivering speaking skill can increase the students' ability. The use of video made students learned the materials authentically. Furthermore, authentic material provides real and actual content of language that promotes significance influence in improving communicative competence.

\section{Conclusion}

The teacher believed that video was defined as one of the aids which was used in the teaching-learning process. The video showed in the classroom was a conversation from English native speaker and animation got from You-tube that was based on the topic studied. It made the students able to learn English as native speakers. She also viewed that the use of video could enhance students' speaking ability. The speaking 
indicators were achieved in the teaching-learning process, namely fluency, vocabulary, pronunciation, grammar, and comprehension. The teacher's role is not only as a facilitator but also as the counselor. Moreover, she defined that a good language teacher should have passion in teaching language. Furthermore, a good language teacher should be able to assess the learning that her or his students have done and made improvement based on those assessments.

The reflection of teacher's beliefs in classroom practices could be seen from some components, such as teacher teaching practices, classroom management, and students' attitudes. In practice, the teacher's role is not only as a facilitator but also as a counselor. Moreover, the teachers managed the class by dividing students into some groups in order to make the passive become motivated in speaking class.

There were some factors which have significant impact in shaping the teacher's beliefs and practices. They consisted of the learning experience, teaching experience, and personality factors. Based on the results, it can be inferred that the teacher's belief in using video is reflected in the classroom practices. It means that there is no gap between teacher's beliefs and teaching practices. 


\section{References}

Ajzen, I., \& Madden, T. J. (1986). Prediction of goal-directed behavior: Attitudes, intentions, and perceived behavioral control. Journal of Experimental Social Psychology, 22, 453- 474

AS, M Saleng, Manurung K, Darmawan. (2014). The Implementation of video learning to improve speaking ability. E-Journal of English Language Teaching Society (ELTS), 2 (3), 2331-1841

Borg, M. (2001). Teachers' beliefs. ELT Journal, 55(2), 186-187

Braun, V., \&Clarke, V. (2006). Using thematic analysis in psychology. Qualitative Research in Psychology, 3(2), 77-101

Breen, M. P., B. Hird, M. Milton, R. Oliver \& A. Thwaite (2001). Making sense of language teaching: teachers' principles and classroom practices. Applied Linguistics, 22 (4), 470-501

Cahyono, B. Y. (1997). Pengajaran Bahasa Inggris: Teknik, Strategi, dan Hasil Penelitian. Malang: Penerbit IKIP Malang

Chen, P. (2011). From CMS to SNA: Educational networking for urban teachers. Journal of Urban Learning, Teaching, and Research, 7, 50-61

Creswell, J.C. (2012). Education research, planning, conducting and evaluating quantitative and qualitative research. 4th edition. Boston: Pearson

Erben, T., Ban, R. \& M. Castañeda. (2009).TeachingEnglish language learners through technology. New York and London: Routledge.

Farrell, S.C. Thomas and Bennis, Karen. (2013). Reflecting on ESL teacher beliefs and classroom practices: A case study. RELC Journal, 44(2), 163-176

Fauziati, E. (2015). Teaching English as a foreign language: Principles and practice. Surakarta: Era Pustaka Utama

Gall, Meredith D., Gall, Joyce, P., and Borg, Walter, R. (2003). Educational research: An introduction, 7th ed. Boston: Pearson Education Inc 
Hakim, M.I.A. Akbar. (2016). The use of video in teaching English speaking (A quasi-experimental research in Senior High School in Sukabumi). Journal of English and Education, 2016, 4(2), 44-48

Harmer, J., (2001). The Practice of English Language Teaching, 3rd ed. London: Longman.

Irawati, Dini. (2016). Supporting student's English speaking achievement using Video. International Journal of EFL, 1(1), 45-60

Kagan, D. M. (1992). Implications of research on teacher belief. Educational Psychologist, 27(1), 65-90

Kennedy, C. (1979). Video in ESP. Teodoro, A. (ed.), RELC Journal, 10(1), 58-69.

Kim, C. M., Kim, K. M, Lee, C., Spector, M., \&DeMeester, K. (2013). Teacher beliefs and technology integration. Teacher Training and Education, 29, 7685

Kojour, Kermani, Masoud and Heirati, Kia, Javad. (2015). Teacher's and students' belief on english for general academic purposes: The case of Iranian University Students. English Language Teaching, 8(12), 37-47

Korthagen, F. A. J. (2004). In search of the essence of a good teacher: Towards a more holistic approach in teacher education. Teaching and Teacher Education, 20, 77-97

Mustikawati, A. (2013). The effectiveness of using video in teaching speaking for the eighth grade students of SMPN 1 Manisrenggo (Unpublished thesis). Yogyakarta State University, Yogyakarta

Octavia, V. S. (2015). The effectiveness of teaching speaking using video narrative to the eight grade students at SMPN 5 Tulungagung in academic year 2014/2015 (Unpublished thesis). Nusantara PGRI University, Kediri

Orawiwatnakul, Wiwat and Wichadeee, Saovapa. (2017). An Investigation of Undergraduate Students' Belief about Autonomous Language Learning. International Journal of Instruction, 10(1), 117-132

Othman, Juliana and Keily, Richard. (2016). Preservice Teachers' Beliefs and Practices in Teaching English to Young Learners. Indonesian Journal of Applied Linguistics, 6(1), 50-59 
Pajares, M. F. (1992). Teachers' beliefs and educational research: Cleaning up a messy construct. Review of Educational Research, 62(3), 307-332

Partnership Forum for 21st-Century Skills. (2008). Maximizing the impact the pivotal role of technology in a 21st century education system. Washington, DC: Partnership for 21st Century Skills

Prestidge, Sarah. (2012) The beliefs behind the teacher that influences their ICT practices. Computers \& Education, (58)1

Richards, J. C. \& Rodgers, T. S. (2001). Approaches and methods in language teaching (2nd ed.). Cambridge, UK: Cambridge University Press

Saleng, M., Manurung, K., \&Darmawan. (2014). The Implementation of video learning to improve speaking ability. E-Journal of English Language Teaching Society (ELTS), 2(3), 1-14

Secer, S. Y. E., Sahin, M., \&Alci, B. (2015). Investigating the effect of audio visual materials as warm-up activity in Aviation English courses on students' motivation and participation at high school level. Procedia - Social and Behavioral Sciences 199, 120-128

Stempleski, S. (2002). Video in the ELT Classroom: The Role of the Teacher. In J. C. Richards, \& W. A. Renandya (Eds.), Methodology in Language Teaching An Anthology of Current Practice (pp.364-367). Cambridge: Cambridge University Press

The Organization for Economic Co-operation and Development (OECD). (2016). Teaching practices, teachers' beliefs and attitudes. Retrieved from https://www.oecd.org/berlin/43541655.pdf

Tuckman, Bruce, W. (1999). Conducting educational research, 5th ed. USA:Harcout Brace and Company

Ur, P. (1996). A course in language teaching: Practice and theory. Cambridge: Cambridge University Press

William, M., \& Burden, R. (1997). Psychology for language teachers. A social constructivist approach. Cambridge: Cambridge University Press 
Ummy Khoirunisya’ Masyhudianti, Hanita Masithoh, Khoirunnisa | 22

$\mathrm{Xu}$, Li. (2012). The role of teachers' beliefs in the language teaching-learning process. Theory and Practice In Language Studies, 2( 7), 1397-1402 